\title{
INDONESIA CBM DEVELOPMENT CHALLENGES AND OPPORTUNITIES
}

\author{
By
}

\author{
S.S. Rita Susilawati \& Hadiyanto \\ Center for Geological Resources
}

\section{INTRODUCTION}

The increasing price of oil in the world market and the depleted national oil reserves while on the other hand there is a high dependency on oil as national main source of energy, promote the development of new energy alternative in Indonesia. Apart from oil, Indonesia is also known to have contained enormous resources of conventional gas, coal, hydropower and geothermal. Furthermore due to its significant coal resources, coalbed methane becomes one of the new promising alternative energy in Indonesia.

\section{METHANE IN COAL}

Methane in coal is an inherent by-product gas of the natural process of coalification during coal formation. It is desorbed and produced from deep coal seams and generated either from a biological process as a result of microbial activity or from a thermal process as a result of increasing heat with depth of the coal. Generally, the higher the coal rank the more methane produced in the coal.

The presence of this gas is very well known particularly in an underground coal mine, for it could create a serious safety risk. Only recently has coal been recognized as a reservoir rock as well as a source rock, thus representing an enormous undeveloped new energy resource.

There are several differences between CBM and conventional gas (Table 1). CBM is stored within the coal by a process called adsorption. Methane is held in the internal surfaces of organic matter - in the pores or matrix of the coal or in the coal cleats. The large internal surface area of the coal allows coal to store 6 to 7 times more gas than the equivalent rock volume of a conventional gas reservoir.
Based on its occurrence, methane in coal can be divided into two categories; Coal Mine methane (CMM) and Coal Bed Methane (CBM). The first one is a terminology applied to methane gas that is released from the remaining coal accumulates in the voids of underground coal mine, diluted with air to the extent of methane concentrations of between $25 \%$ and $70 \%$ and can be commercially recovered. The second one is a terminology applied to the methane still trapped in unworked coal seams which possible representing a promising new energy resource.

Table 1. Differences between CBM and Conventional Gas

\begin{tabular}{|c|c|c|}
\hline Differences & CBM & $\begin{array}{l}\text { Conventional } \\
\text { gas }\end{array}$ \\
\hline $\begin{array}{c}\text { Source and } \\
\text { Reservoir }\end{array}$ & $\begin{array}{c}\text { Coal as } \\
\text { source and } \\
\text { reservoir }\end{array}$ & $\begin{array}{c}\text { Source and } \\
\text { reservoir are } \\
\text { independence }\end{array}$ \\
\hline $\begin{array}{c}\text { Gas } \\
\text { characteristic }\end{array}$ & $\begin{array}{c}\text { Adsorbed } \\
\text { within the } \\
\text { coal }\end{array}$ & $\begin{array}{c}\text { Migrate up to } \\
\text { reservoir }\end{array}$ \\
\hline $\begin{array}{c}\text { Occurrences } \\
\text { at depth }\end{array}$ & $\begin{array}{c}\text { Shallow } \\
400-1500 \\
\text { feet }\end{array}$ & $\begin{array}{c}\text { Deep 4000- } \\
12.000 \text { feet }\end{array}$ \\
\hline Storage & $\begin{array}{c}\text { Initially } \\
\text { large } \\
\text { volume } \\
\text { water }\end{array}$ & $\begin{array}{c}\text { Large volume } \\
\text { gas }\end{array}$ \\
\hline
\end{tabular}

The extraction of methane from the coal seam can be done by drilling the coal seam (200 - 1500 meters) or pumping the water from the coalbed. Water usually fills fractures or cleats in the coalbeds. In order for gas to be released from the coal, its partial pressure must 
be reduced, and this is accomplished by removing water from the coalbed. Water moving from the coal seam to the well bore can decrease pressure within the coal seam. As CBM has very low solubility in water and readily separate as pressure decrease, drilling and water pumping process encourages gas migration toward the well. Methane gas then is sent to a compressor station and into natural gas pipelines. On the other hand, the produced water can be reinserted into isolated formations, released into streams, or used for irrigation (Figure 1).

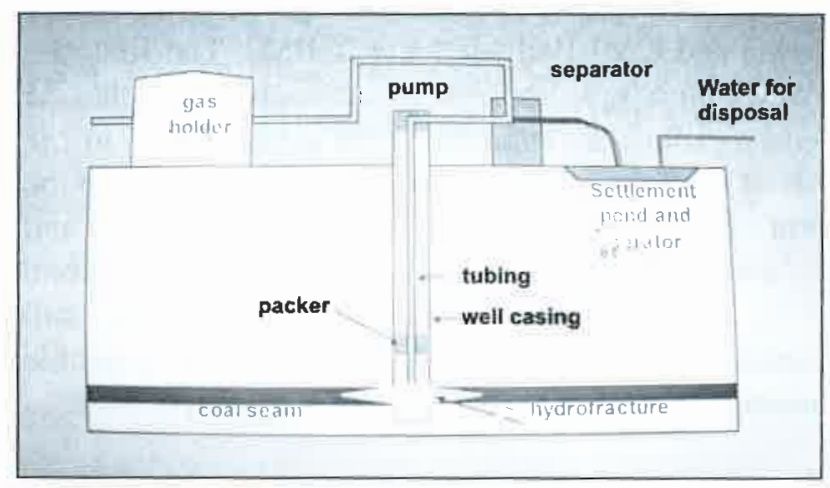

Figure 1. The Coal Bed Methane Concept (After British Geological Survey, 2005)

\section{CBM AS NEW ENERGY ALTERNATIVE IN INDONESIA}

Whereas in some other countries CBM has been developed and commercialized (Table 2), CBM development in Indonesia is still in early stage of development. There are several backgrounds that promote CBM as a new promising energy alternative in Indonesia:

\section{The increasing of oil price in the world market.}

This condition significantly hits Indonesia's economic which since the world economy crisis in 1997 has not been fully recovered. The worst condition occurred due to firstly, dependency on the oil as Indonesia main source of energy, and secondly depletion of national oil reserve and fast growing in national energy demand. Recently, as Indonesia becomes a net oil importer, government policy in subsidizing the oil price for domestic uses significantly influencing country financial condition. The government has to provide a big capital to cover the differences between the price of oil in the world market and in domestic market. Energy crisis occurred in Indonesia when the government could not afford to buy the oil, as its price increases unpredictable. A strong commitment has been declared to reduce the dependency on the oil as national main source of energy, as soon as possible.

\section{Indonesia huge amount of coal resources.}

Coexisting with coal deposit is CBM. Development of CBM will benefit the national energy supply and energy conservation program. It is widely known that using coal as source of energy such as in power generation is generally considered to produce emissions of green house gasses. Coalbed methane, on the other hand, is believed being a kind of energy source that environmentally more acceptable than coal combustion. The emission of $\mathrm{CO}_{2}$ from $\mathrm{CBM}$ is far below $\mathrm{CO}_{2}$ emission from coal burning.

Tabel 2. Methane recovery and use in selected countries

\begin{tabular}{|c|c|c|}
\hline Country & Methane Recovery & Methane Use \\
\hline China & $561 \times 106 \mathrm{M} 3$ & $\begin{array}{l}\text { Heating, Cooking, Glass And Plastics Industries, Feedstock O } \\
\text { Carbon Black, Power Generation }\end{array}$ \\
\hline $\begin{array}{l}\text { Russia, Ukraine, } \\
\text { Kazakstan }\end{array}$ & $1000 \times 106 \mathrm{M3}$ & $\begin{array}{l}\text { Heating Mine Facilities, Metallurgical Industry, Motor Vehicle } \\
\text { Fuel, Power Generation }\end{array}$ \\
\hline $\begin{array}{l}\text { The United } \\
\text { States }\end{array}$ & $1195 \times 106 \mathrm{M} 3$ & Town Gas-Pipeline, Power Generation, On-Site Mine Use \\
\hline Germany & $520 \times 106 \mathrm{M3}$ & Heating, Power Generation \\
\hline United Kingdom & $200 \times 106 \mathrm{M} 3$ & $\begin{array}{l}\text { Generate Steam For Mine Facilities, Town Gas, Power } \\
\text { Generation }\end{array}$ \\
\hline Australia & $122 \times 106 \mathrm{M} 3$ & Power Generation \\
\hline
\end{tabular}




\section{HISTORY OF CBM DEVELOPMENT IN INDONESIA}

CBM survey in Indonesia actually has been conducted almost the same time as those of coal mining. However, in the past this survey was done only for mining safety reason. The first survey of CBM as energy sources is begun in 1998, conducted by Caltex and Pertamina. This first CBM survey is important because it opens a new look of CBM prospect in Indonesia. After 1998, several CBM studies have carried out coordinated by Ministry of Mines and Energy.

The most recent and more comprehensive CBM survey in Indonesia did by The Directorate of Oil and Gas collaborated with Advances Resources International (ARI) and funded by ASEAN Development Bank, in 2002 (reported 2003). Based on this survey, it is estimated that Indonesia has CBM potency about 450 Trillions Cubic Feet (Tcf). The survey has also looked more closely at several aspects of CBM such as exploration and exploitation in Indonesia, basins evaluation as well as CBM reservoir properties evaluation.

\section{INDONESIA CBM POTENTIAL}

Current CBM survey in Indonesia has indicated about 450Tcf potentially CBM resources in some onshore coal basins screened at the depth ranging from 500 to $4500 \mathrm{~m}$. In general two primary ages of coal deposits present in Indonesia that is prospective for CBM development (Table 3).

Miocene coal deposits considered as the most prospective. Although relatively low in rank (Ro 0.3$0.5 \%$ ), they are extremely thick (over $30 \mathrm{~m}$ of net coal). These coal are relatively shallow, high in moisture and extremely low in ash content. Eocene coal deposits although high in rank, are less attractive because they are normally thinner and deeper coals. However, some of those coals may be locally prospective as well.

In general, coal in Indonesia is considered low rank and relatively shallow to contain prospective CBM. However, the success in developing low rank CBM in Powder River Basin USA and the improvement of understanding that the shallow coal seams mined at the surface in Indonesia are dip basin ward and become gas charged at target depths over broad areas, also strong and nearly ubiquitous gas kick recorded in some oil wells that penetrated the coal seam, have indicated the potential of CBM resources in low rank coal of Indonesia (Hadiyanto \& Stevens, 2005).

Table 3.

Characteristics of Indonesia two primary ages' coal deposits that is prospective for CBM development

\begin{tabular}{|l|l|}
\hline Miosen coal formation & Eosen coal formation \\
\hline $\begin{array}{l}\text { Typically thick } \\
\text { (over } 30 \text { m of net coal) }\end{array}$ & $\begin{array}{l}\text { Thin to moderately thick } \\
(1-10 \mathrm{~m} \text { net) coal deposits, }\end{array}$ \\
\hline Low rank (Ro 0.3-0.5\%) & $\begin{array}{l}\text { Low to moderate rank } \\
>0.5 \%\end{array}$ \\
\hline $\begin{array}{l}\text { Relatively shallow (outcrop } \\
\text { to } 1000 \mathrm{~m}),\end{array}$ & $\begin{array}{l}\text { Typically buried much } \\
\text { deeper (1000-2000m) }\end{array}$ \\
\hline $\begin{array}{l}\text { High in moisture, extremely } \\
\text { low in ash content }\end{array}$ & $\begin{array}{l}\text { Less attractive as CBM } \\
\text { target due to their thinner }\end{array}$ \\
\hline $\begin{array}{l}\text { Presenting attractive CBM } \\
\text { completion targets }\end{array}$ & $\begin{array}{l}\text { and deeper coals, but may } \\
\text { be locally prospective }\end{array}$ \\
\hline
\end{tabular}

Based on geology, inferred reservoir quality, proximity to gas markets, drilling infrastructure and other factors, ARI survey has been ranked Indonesia's coal basins into the top most high graded CBM basin in Indonesia (Table 4). Table 4 shows that The South Sumatra basin is the most prospective area for CBM development, followed by The Barito and Kutei Basins. CBM resources in South Sumatra basin are estimated at $183 \mathrm{Tcf}$, with resource concentrations of up to 0.7 billion $\mathrm{m}^{3} / \mathrm{km}^{2}$. The Barito basin has an estimated 102 Tcf resource, while CBM in the Kutei is estimated at 80 Tcf resources. About 53 Tcf resource is estimated to be present in the Central Sumatra basin but coal seams are mainly thinner and occur at greater depth.

Indonesia Coal reservoir properties are still poorly characterized. A CBM survey by Department of Mineral Resources Indonesia in 1999, has determined methane adsorption isotherms in some selected low rank coal samples from Sumatra and Kalimantan. Samples were taken mainly from shallow outcrops or coal mines. Results indicate that sorptive capacity varies widely with rank $\left(15 \mathrm{~m}^{3} / \mathrm{t}\right.$ in high volatile $\mathrm{C}$ coal and $4.7-8.1 \mathrm{~m}^{3} / \mathrm{t}$ in sub bituminous coal). Good correlation existed between vitrinite reflectance of the coal samples and adsorption capacity. Result of the study suggested that increase in vitrinite reflectance or coal rank corresponded to increase in gas adsorption 


\section{HISTORY OF CBM DEVELOPMENT IN INDONESIA}

CBM survey in Indonesia actually has been conducted almost the same time as those of coal mining. However, in the past this survey was done only for mining safety reason. The first survey of CBM as energy sources is begun in 1998, conducted by Caltex and Pertamina. This first CBM survey is important because it opens a new look of CBM prospect in Indonesia. After 1998, several CBM studies have carried out coordinated by Ministry of Mines and Energy.

The most recent and more comprehensive CBM survey in Indonesia did by The Directorate of Oil and Gas collaborated with Advances Resources International (ARI) and funded by ASEAN Development Bank, in 2002 (reported 2003). Based on this survey, it is estimated that Indonesia has CBM potency about 450 Trillions Cubic Feet (Tcf). The survey has also looked more closely at several aspects of CBM such as exploration and exploitation in Indonesia, basins evaluation as well as CBM reservoir properties evaluation.

\section{INDONESIA CBM POTENTIAL}

Current CBM survey in Indonesia has indicated about 450 Tcf potentially CBM resources in some onshore coal basins screened at the depth ranging from 500 to $4500 \mathrm{~m}$. In general two primary ages of coal deposits present in Indonesia that is prospective for CBM development (Table 3).

Miocene coal deposits considered as the most prospective. Although relatively low in rank (Ro 0.3$0.5 \%$ ), they are extremely thick (over $30 \mathrm{~m}$ of net coal). These coal are relatively shallow, high in moisture and extremely low in ash content. Eocene coal deposits although high in rank, are less attractive because they are normally thinner and deeper coals. However, some of those coals may be locally prospective as well.

In general, coal in Indonesia is considered low rank and relatively shallow to contain prospective CBM. However, the success in developing low rank CBM in Powder River Basin USA and the improvement of understanding that the shallow coal seams mined at the surface in Indonesia are dip basin ward and become gas charged at target depths over broad areas, also strong and nearly ubiquitous gas kick recorded in some oil wells that penetrated the coal seam, have indicated the potential of CBM resources in low rank coal of Indonesia (Hadiyanto \& Stevens, 2005).

Table 3 ,

Characteristics of Indonesia two primary ages' coal deposits that is prospective for CBM development

\begin{tabular}{|l|l|}
\hline Miosen coal formation & Eosen coal formation \\
\hline $\begin{array}{l}\text { Typically thick } \\
\text { (over } 30 \text { m of net coal) }\end{array}$ & $\begin{array}{l}\text { Thin to moderately thick } \\
(1-10 \mathrm{~m} \text { net) coal deposits, }\end{array}$ \\
\hline Low rank (Ro 0.3-0.5\%) & $\begin{array}{l}\text { Low to moderate rank } \\
>0.5 \%\end{array}$ \\
\hline $\begin{array}{l}\text { Relatively shallow (outcrop } \\
\text { to } 1000 \mathrm{~m}),\end{array}$ & $\begin{array}{l}\text { Typically buried much } \\
\text { deeper (1000-2000m) }\end{array}$ \\
\hline $\begin{array}{l}\text { High in moisture, extremely } \\
\text { low in ash content }\end{array}$ & $\begin{array}{l}\text { Less attractive as CBM } \\
\text { target due to their thinner }\end{array}$ \\
\hline $\begin{array}{l}\text { Presenting attractive CBM } \\
\text { completion targets }\end{array}$ & $\begin{array}{l}\text { and deeper coals, but may } \\
\text { be locally prospective }\end{array}$ \\
\hline
\end{tabular}

Based on geology, inferred reservoir quality, proximity to gas markets, drilling infrastructure and other factors, ARI survey has been ranked Indonesia's coal basins into the top most high graded CBM basin in Indonesia (Table 4). Table 4 shows that The South Sumatra basin is the most prospective area for CBM development, followed by The Barito and Kutei Basins. CBM resources in South Sumatra basin are estimated at $183 \mathrm{Tcf}$, with resource concentrations of up to 0.7 billion $\mathrm{m}^{3} / \mathrm{km}^{2}$. The Barito basin has an estimated $102 \mathrm{Tcf}$ resource, while CBM in the Kutei is estimated at 80 Tcf resources. About 53 Tcf resource is estimated to be present in the Central Sumatra basin but coal seams are mainly thinner and occur at greater depth.

Indonesia Coal reservoir properties are still poorly characterized. A CBM survey by Department of Mineral Resources Indonesia in 1999, has determined methane adsorption isotherms in some selected low rank coal samples from Sumatra and Kalimantan. Samples were taken mainly from shallow outcrops or coal mines. Results indicate that sorptive capacity varies widely with rank $\left(15 \mathrm{~m}^{3} / \mathrm{t}\right.$ in high volatile $\mathrm{C}$ coal and $4.7-8.1 \mathrm{~m}^{3} / \mathrm{t}$ in sub bituminous coal). Good correlation existed between vitrinite reflectance of the coal samples and adsorption capacity. Result of the study suggested that increase in vitrinite reflectance or coal rank corresponded to increase in gas adsorption 
capacity (Hadiyanto and Saghafi, 2000). A higher sorptive capacity is expected in coals at CBM target depth which is higher in rank and lower in moisture (Hadiyanto and Steven, 2005).

Only limited number of gas content desorption measurement has taken place. CBM pilot project by Lemigas in 2006, has drilled two CBM wells in Rambutan Areas South Sumatra Basin, with target depth of $610 \mathrm{~m}$ and $950 \mathrm{~m}$ respectively. The gas content values for the CBM-1 well varied from 0.5 $3.6 \mathrm{~m}^{3} /$ ton, with the Seam-3 contains the highest gas content. Samples from the second well are being analyzed so there is no data yet (Legowo, 2006). During drilling of CBM-2 well, gas kick has been shown from the top of Seam-3, suggesting that the seam rich of free gas (Legowo, 2006). experiencing only local compression or transpressional forces that suggest possible low horizontal stress and favorable permeability (Hadiyanto and Steven, 2005).

\section{EFFORTS TO DEVELOP INDONESIA CBM}

CBM producibily is controlled by gas content, depositional setting, tectonic setting, hydrodynamics and permeability (Scott, 1997), which are specific to each coal basin. Although recent survey has identified and characterized some coal basins to be highly prospective, this survey is only a preliminary study. It means that detailed geologic evaluation for each basin is still needed, in order to find sweet spots for CBM development in those basins.

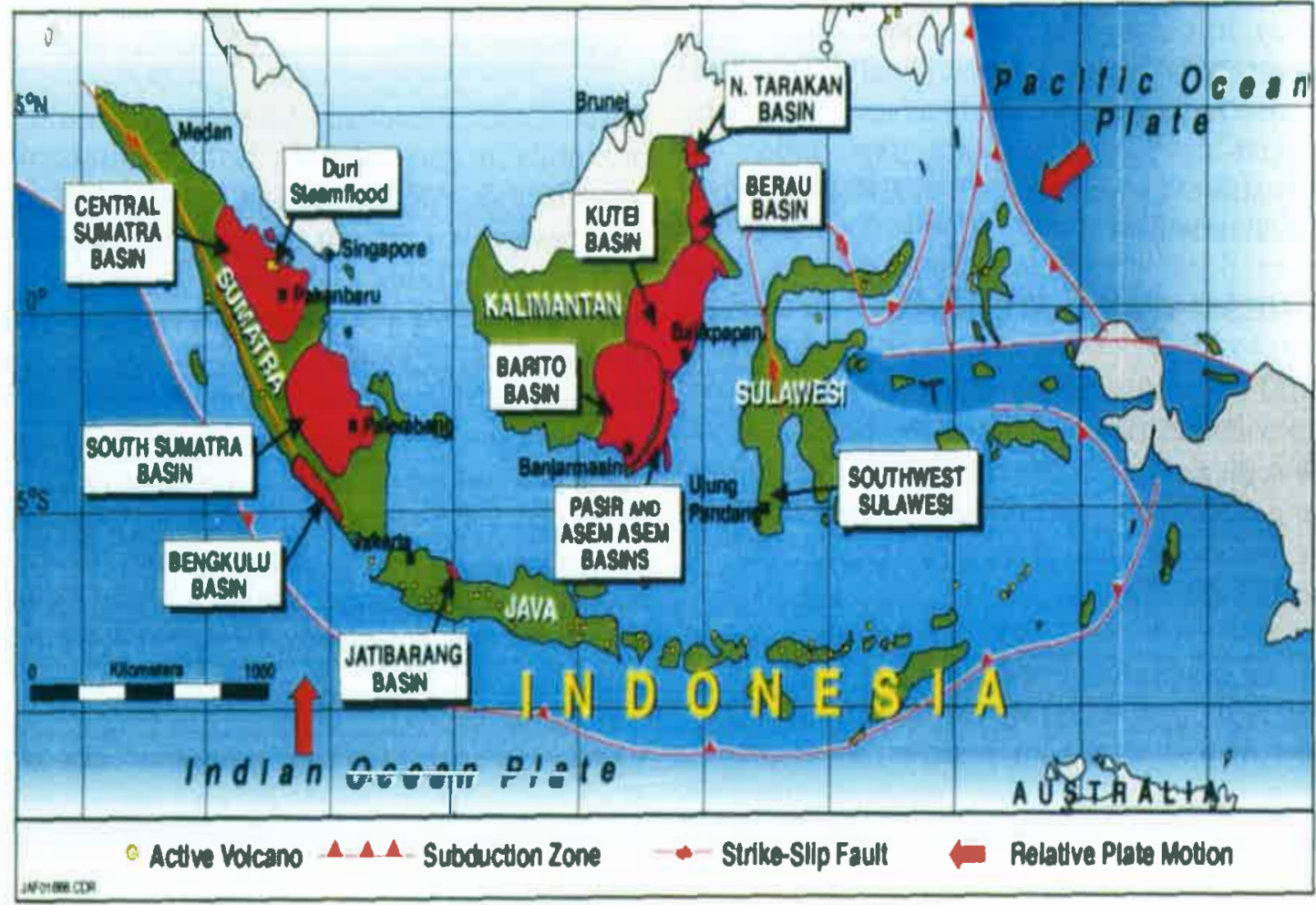

Figure 2. Indonesia CBM Basins (ARI, 2003)

Up to know there is no data on in situ coal seam permeability. Cleat development at shallow outcrops and coal mine locations generally is poor but coal typically is high in vitrinite content which could promote cleat development in the deeper mature coals. Most coal basins are tectonically extensional,
ARI (2003) has proposed to test the most promising site as one of the efforts to establish Indonesia CBM industry. Currently, Indonesia has a national CBM pilot project in South Sumatra Basin, under Lemigas management, a government institution that responsible for oil and gas development. This project includes 
finalization of rules and regulation for CBM businesses, pilot project on CBM exploitation, prospect rating of CBM resources in Indonesia and preparation of both the utilization technology for CBM and underground coal gasification of post CBM production. The projects also try to develop a centre of excellence for CBM exploration and production in Indonesia. The project is scheduled to be finished by the end of year 2007 .

Table 4.

The most prospective CBM Basin in Indonesia Based on ARI survey (2000)

\begin{tabular}{|l|l|c|c|}
\hline $\begin{array}{l}\text { Overall } \\
\text { rank } \\
(4.0=\text { top })\end{array}$ & Basin & $\begin{array}{l}\text { Prospective } \\
\text { Areas }\left(\mathrm{Km}^{2}\right)\end{array}$ & $\begin{array}{l}\text { CBM } \\
\text { resources } \\
\text { (Tcf) }\end{array}$ \\
\hline 3.7 & $\begin{array}{l}\text { South } \\
\text { Sumatra }\end{array}$ & 7,35 & 183 \\
\hline 3.1 & Barito & 6,33 & 102 \\
\hline 3.1 & Kutai & 6,1 & 80 \\
\hline 3.0 & $\begin{array}{l}\text { Central } \\
\text { Sumatra }\end{array}$ & 5,15 & 53 \\
\hline & $\begin{array}{l}\text { All } \\
\text { Basins }\end{array}$ & 30,248 & 453 \\
\hline
\end{tabular}

At present, Center for Geological Resources, the institutions under Geological Agency which has the mission in enhancing the finding of new potential mineral, oil and gas (including CBM), coal, peat, oil shale and geothermal resources areas in Indonesia, also carries out some CBM surveys and investigations. The main focus of CGR works is to characterize the most prospects of Indonesia CBM basin through detail basin evaluation and gas content measurement. CGR also has a concern in educating its expert on CBM. This year, the institution will send two geologists to undertake a short course in the USA, a CBM leading country which has experienced in managing lower rank coal CBM.

Establishing a legal regulatory framework for CBM businesses is also another crucial point in developing $\mathrm{CBM}$ business in Indonesia. CBM needs special regulation because of its mining characteristic is different from conventional gas. In the first stage of CBM exploitation, high cost investment might be required, as the precondition to apply special treatment to CBM reservoir, in order to stimulate gas flow towards the well. The peak production of CBM commonly achieved after 5 to 7 years operation compared to 1 year for conventional gas. Thus, in order to commercialize CBM potency, the government should offer attractive incentives for the CBM operators. Yet, the contract model for CBM industry in Indonesia is still being discussed and formulated which is planned to be finalized in 2007.

\section{CHALLENGES FACING BY CBM DEVELOPMENT IN INDONESIA}

In general, challenges facing by CBM development in Indonesia can be divided into technical and operational challenges. Lack of Information and knowledge about CBM, lack of capital, non experienced human resources, limited expert and CBM regulation is still being formulated, are considered to become some technical challenges. On the other hand, some operational challenges that should be anticipated are including high water production, lower coal seam permeability (poor cleat development) as well as swampy and remote in many CBM prospective areas which need infrastructure development and high cost CBM test (Hadiyanto and Steven, 2005).

In order to anticipate those challenges, it is important to find a partner from experienced and active company in CBM exploration-exploitation to share their knowledge to the prospective CBM areas, as well as promoting CBM exploration and exploitation in Indonesia through favorable legislations, policies and investment climates. On the other hand, some strategies might be applied to anticipate operational problems

Hadiyanto and Steven (2005), have suggested applying conventional vertical wells to anticipate poor surface access. Learning from Indonesia petroleum service sector which already has experienced in mature oil fields and enhancing oil recovery which in many ways resemble CBM operations, can also be useful. For instance thousands of closely spaced wells developed on swamp lands in Duri fields. There is an extremely high water production in these fields, but yet 
technically and environmentally manageable (Hadiyanto and Steven, 2005).

A hydraulic stimulation with 1 to 3 fracs per well may be applied to anticipate low permeability coal while a horizontal drilling could be done to mitigate construction cost and environmental impacts (Hadiyanto and Steven, 2005). In order to reduce development risk, Indonesia can conduct a property test of coal seam targets in conventional oil and gas wells or implementing low cost program in expendable core holes, using in country mining rigs that could drill test CBM coreholes quickly and cheaply (Hadiyanto and Steven, 2005).

\section{OPPORTUNITIES TO DEVELOP INDONESIA CBM}

Some opportunities that lead to development of Indonesia's CBM:

Global demand of electricity especially in the ASEAN region.

The depletion of oil as a main source of energy, while on the other hand there is an increasing demand on energy, promote the used of other energy alternative including CBM. Two advantages using CBM as energy sources for electricity are, firstly the heat efficiency is higher than using coal and secondly the environmentally hazard potency could be reduced. For instance, A300 Mega Watt (MW) combined-cycle (gas/steam) plant has a thermal efficiency of approximately 46 percent better than the $600 \mathrm{MW}$ coal-fired plants. The cost of a combined-cycle plant is approximately 33 percent less than that for an equivalent coal-fired plant.

National awareness on energy conservation program.

The energy crisis occurs in Indonesia recently, increases national awareness on energy efficiency and conservation program. Indonesian Government has issued a national energy policy as a blue print for energy mix by year 2025 to secure energy supply for domestic needs. One of the government policies is aimed to reduce oil consumption significantly down to $20 \%$ and encouraging the use of natural gas and coal more than $30 \%$ and $33 \%$ respectively, as well as encouraging the use of alternative energy sources for

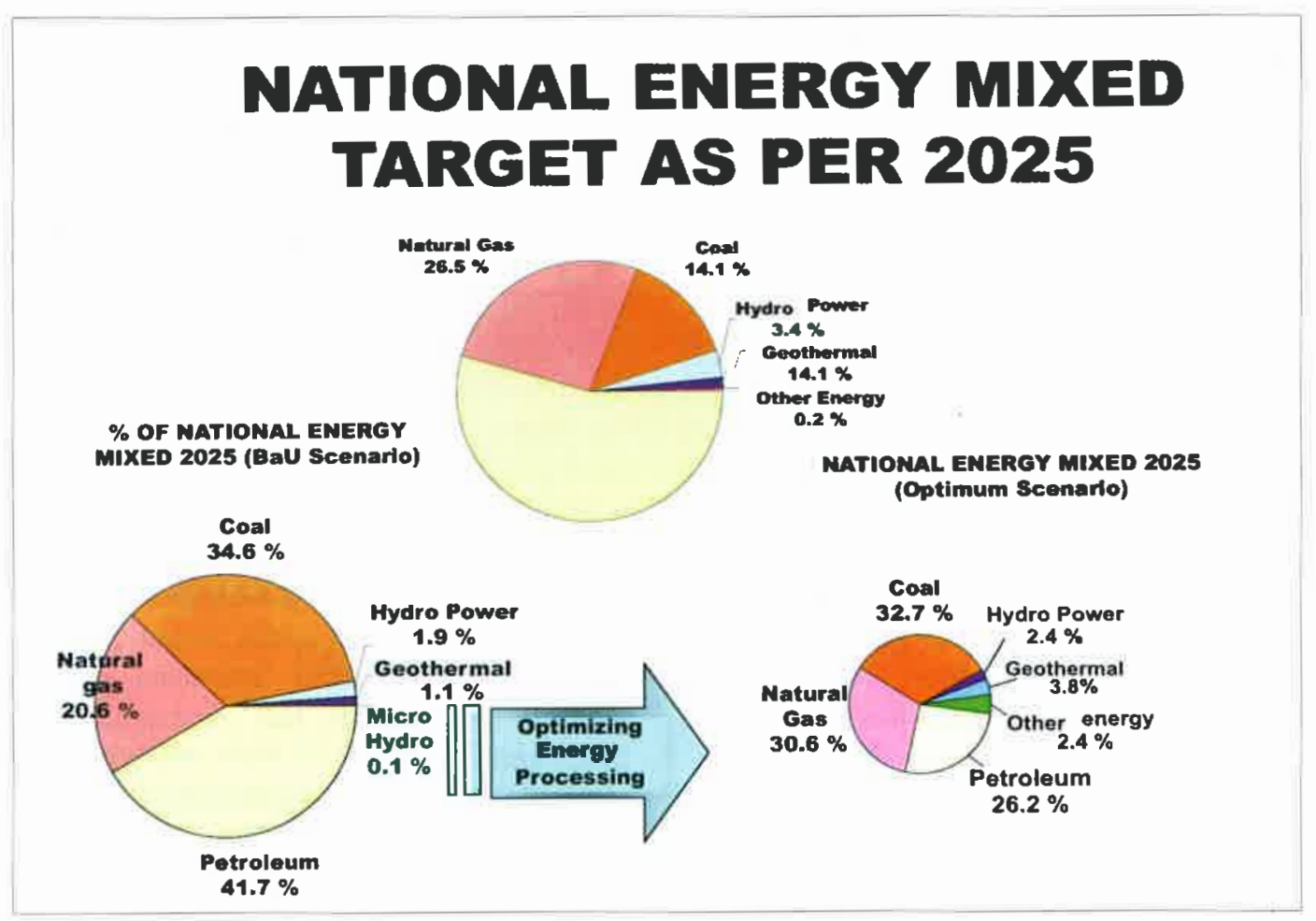

Figure 3. Indonesia energy mixed policy 
domestic needs as much as $17 \%$. It means that the government will support all research and effort in developing new energy alternative in Indonesia, which will also give a benefit to investment climate condition in the development of CBM.

\section{Environmental Concern}

Recent concern on environment issues such as $\mathrm{CO}_{2}$ emissions is considered to become a support in the development of CBM. Using CBM as an energy source in power generation has been known in producing less $\mathrm{CO}_{2}$ emissions. For example, $\mathrm{CO}_{2}$ emissions per unit of electricity generated from Brown Coal is 1,180 tones per GWh (Gega Watt Hour) compared to 25 tones per GWh for CBM and 600 tones per GWh for Black Coal. CBM is also free of sulphur and thus it does not generate sulphur oxides which are known as the source of both pollution and "acid rains" when it is burnt. Other advantages of CBM development is possible $\mathrm{CO}_{2}$ sequestration. Coal seam can be used for $\mathrm{CO}_{2}$ sequestration which will reduce $\mathrm{CO}_{2}$ emissions. Naturally $\mathrm{CO}_{2}$ molecules are more easily to be bound by coal organic component than of methane gas molecules. Thus if one $\mathrm{CO}_{2}$ molecule fills coal component, there will be one methane gas released in order to maintain its chemical stability. This phenomenon will increase CBM production from one reservoir which is called enhanced CBM recovery and also will reduce $\mathrm{CO}_{2}$ emissions. Another advantage from $\mathrm{CO}_{2}$ sequestration comes from Clean Development Mechanism (CDM) project. The CDM project states that all developed countries which sign the Kyoto Protocol must reduce their $\mathrm{CO}_{2}$ emissions. In accordance with that responsibility, the developed countries must give some incentives to any developing countries that able to reduce their $\mathrm{CO}_{2}$ emission. It means that with conducting $\mathrm{CO}_{2}$ sequestration in coal seam could increase CBM producibility, as well as receiving incentives from $\mathrm{CDM}$ project.

\section{Proximity to potential gas market.}

As a result of the oil crisis of the 70's and 80's ASEAN countries have pursued programs to reduce oil consumption and increase natural gas use (Balce, 2003). In 1997, the ASEAN vision 2020 included the Trans ASEAN gas Pipeline (TAGP) among its major infrastructure projects to secure the availability of natural gas in the demand centers of the region (Balce, 2003). The development of CBM industry in Indonesia is benefited by proposed TAGP and ASEAN Power Grid. Indonesia $\mathrm{CBM}$ can supply the natural gas

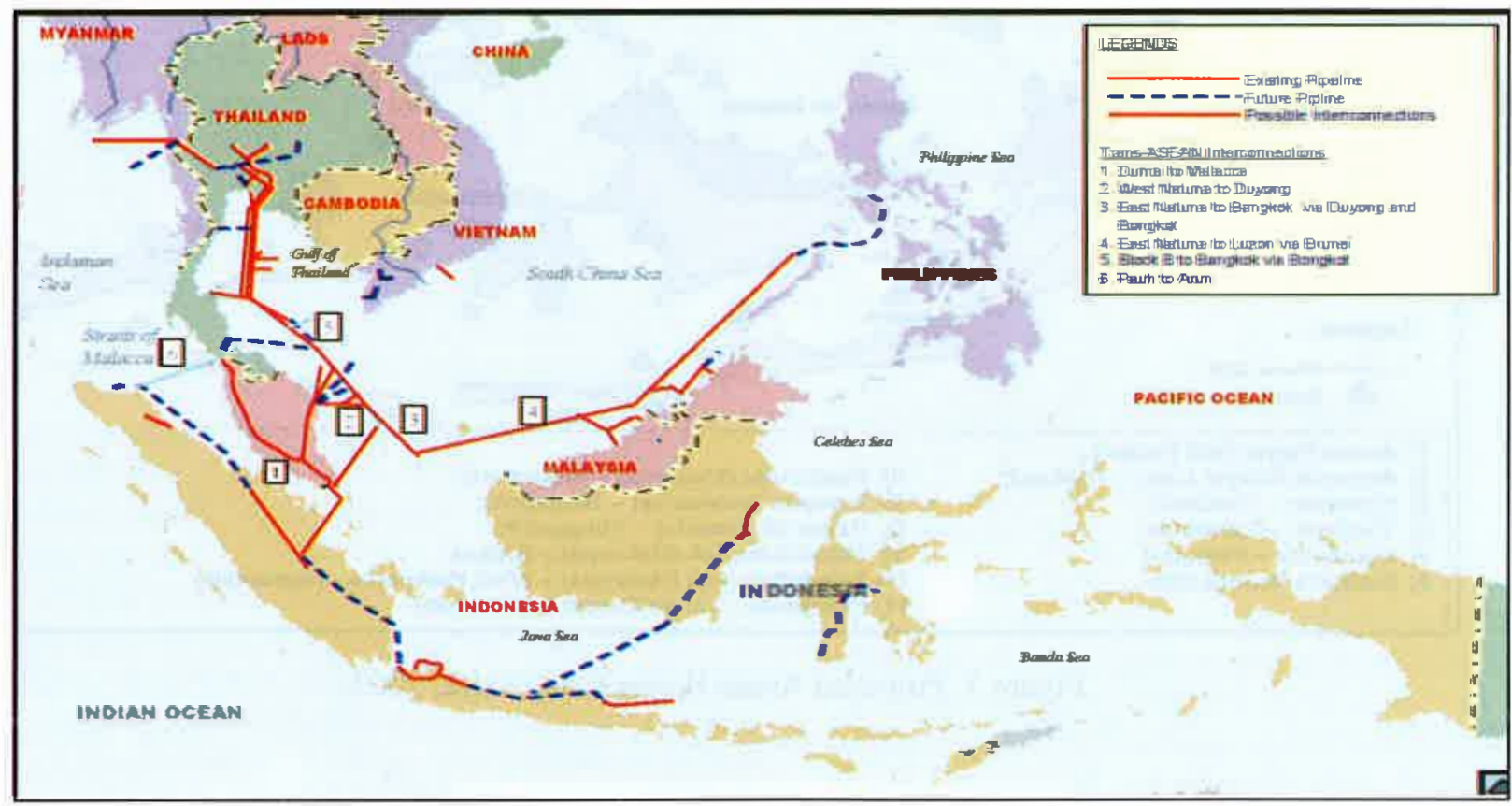

Figure 4. Proposed Trans Asean Gas Pipeline (Balce, 2003) 


\section{Buletin Sumber Daya Geologi Volume 1 Nomor 1 - 2006}

reserves through Trans - ASEAN gas pipeline networks (Figure 4) and feed the increasing demand of electricity in this area through ASEAN power grid (Figure 5).

The development of underground coal mining.

The safety of underground coal mining is greatly improved by in-seam or surface gas drainage operation. On the other hand, faster mining rates are possible in degassing coals which will lower the production costs. Degassing coal also enables the deeper mining to be reached which will increase reserve size. It means there will be a mutual relationship between coal mining operator and CBM operator.

\section{CLOSING REMARK}

CBM is a potential energy resource in Indonesia. Some conditions favor the development of CBM in Indonesia. Promotion of CBM exploration and exploitation are needed through favorable legislations, policies and investment climates. Capacity building through transfer of knowledge on CBM-producing countries to Indonesia will foster the development of $\mathrm{CBM}$ in this region and open a new business opportunities. Detail CBM surveys or investigations are still needed in order to characterize well the geological condition of Indonesia CBM basins.

\section{ACKNOWLEDGMENT}

Thank is expressed to the editor for suggestions and corrections, which significantly has improved this paper.

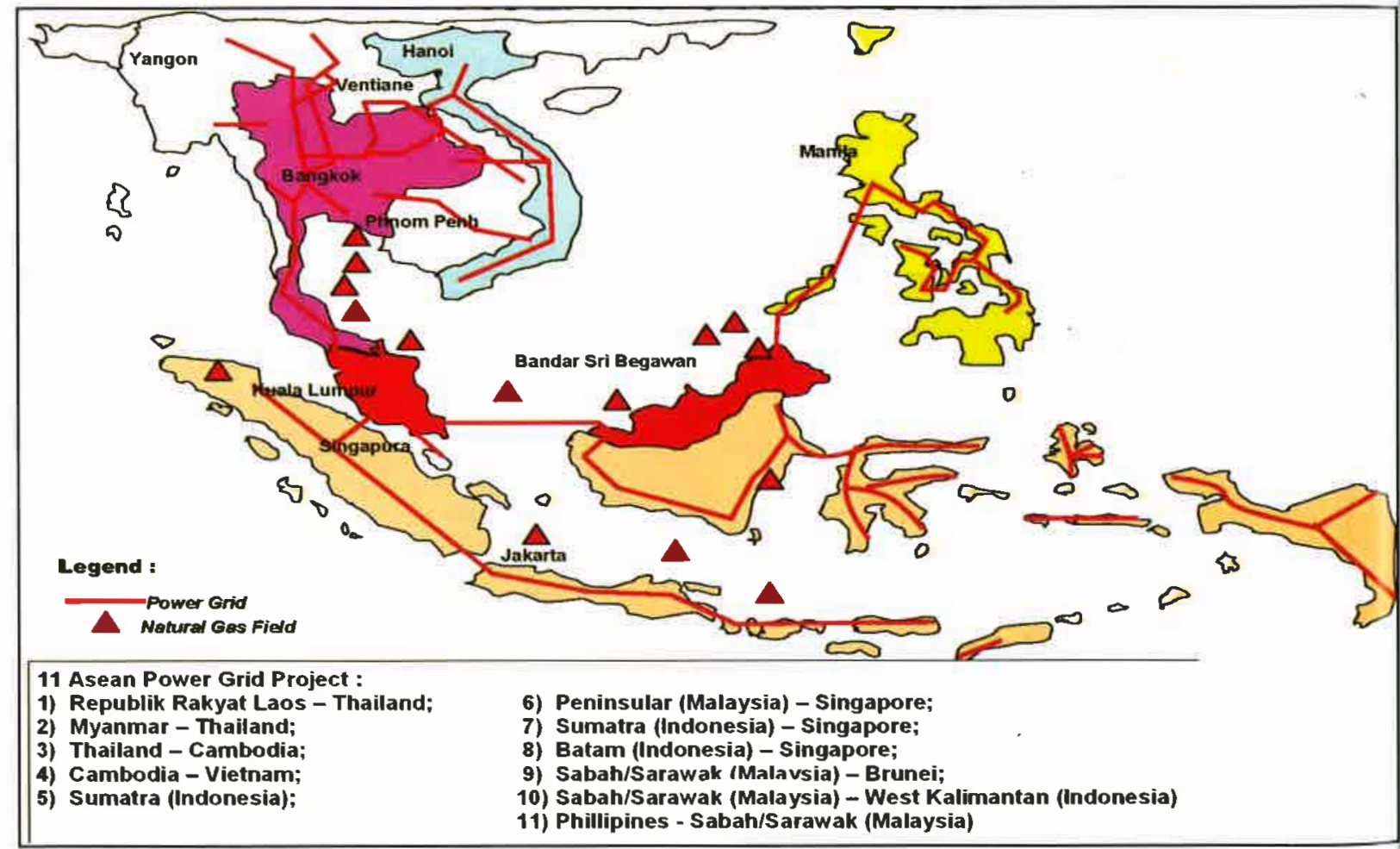

Figure 5. Proposed Asean Power Grid (Balce, 2003) 


\section{REFERENCES :}

Advanced Resources International Inc, (ARI)., 2003. Indonesian Coalbed methane. Task I Resource Assessment, Final draft prepared for Asean Development Bank and MIGAS, Jakarta, Indonesia, 2003.

Balce G.R., 2003. Natural Gas Utilization, Infrastructure and Resources, Prospect for Coalbed methane in the ASEAN region, Coalbed methane Workshop, Ministry of Mine and Energy The Republic of Indonesia, Jakarta Indonesia, 2003.

British Geological Survey., 2005. Mineral Profile, Coal. Office of the Deputy Prime Minister, 2005.

Hadiyanto and Saghafi, A., 2000. Methane Storage Properties of Indonesian Tertiary Coals. Proceedings of the Southeast Asean Coal Geology Conference, Bandung, Indonesia, 19-20 June, 2000.

Hadiyanto and Stevens S.H., 2005. Coalbed methane Prospects in Lower Rank Coals of Indonesia, IAGI Special issues - Indonesia Mineral and Coal Discoveries, 2005.

Legowo E.H, 2006. Current Status of CBM Development in Indonesia. Indo CBM Conference, Jakarta Indonesia, April 2006.

Scott A.R and Tyler R., 1998. Geologic and Hydrologic Controls Critical to Coalbed methane Production and Resource Assessment, Bureau of Economic Geology, The University of Texas at Austin. 